\title{
Interrelation between anthropology and psychology in the works of St. Theophan the Recluse
}

\section{Hieromonk Iriney (Pikovskiy)}

Sretenskaja Theological Seminary,

19, ul. Bolshaya Loubyanka, Moscow, 107031, Russian Federation

For citation: Pikovskiy I.V. Interrelation between anthropology and psychology in the works of St. Theophan the Recluse. Issues of Theology, 2021, vol. 3, no. 1, pp. 45-57. https://doi.org/10.21638/spbu28.2021.103

The works of bishop Theophan (Govorov) the Recluse on Christian ethics are considered fundamental in studying the history of the formation of Christian psychology in Russia. The style, narrative and vocabulary of the works echo his Russian edition of the "Philokalia". However, contrary to the common perception that Saint Theophan the Recluse thought exclusively in the language of Holy Fathers, the present study provides examples showing that the saint borrowed some ideas from the classical German philosophy of romanticism. Under the influence of his teachers from the Kiev Theological Academy (P.A. Avsenev), he addresses the subject of the "human spirit". Arguing with representatives of natural philosophy, whose names he does not mention, Theophan asserts that the spirit is the highest faculty of human nature, the breath of life, the image of God, which enables man to communicate with the Creator. For St. Theophan, as for many other academic scholars of the mid-19th century, "moral philosophy", "anthropology" and "psychology" were interchangeable concepts. As shown in this study, in matters of psychology and pedagogy, the reflections of Theophan the Recluse are based on the same model that was actively developed by the philosophers of modern times (Schelling, Hegel). Despite serious worldview differences in relation to religion, Saint Theophan reads, filters and continues to develop some ideas that originated in German philosophy.

Keywords: anthropology, psychology, person, personality, Russian theology, St. Theophan the Recluse, upbringing, vow of baptism.

The first steps towards the development of psychology as a separate humanitarian discipline in Russia were taken at the beginning of the $19^{\text {th }}$ century. The search for the anthropological foundations of the pedagogical theory and practice ran between ascetic theology and moral philosophy. The "Philokalia" (Фı入ока入ía) of St. Paisius Velichkovsky published in Slavonic in 1793 aroused interest in hesychasm, which was perceived not only as a monastic practice of contemplative life, but also as a subject for an academic research. At almost the same time, the works of German idealists such as Hegel, Schelling and Fichte began to penetrate into Russia and were read with enthusiasm not only in universities, but also in theological academies in Kiev, Moscow and St. Petersburg.

(C) St. Petersburg State University, 2021

(c) Ss. Cyril and Methodius Theological Institute of Postgraduate and Doctoral Studies, 20212021 
Some praised the German philosophers, others criticized them, but everyone read them ${ }^{1}$. Theophan the Recluse was among those who appealed to both the holy fathers and the philosophical terminology of the Modern Era. In the teaching on the "human spirit", he relied not only on Apostle Paul, but also on the terminology of the representatives of German romanticism².

The future bishop, Theophan Govorov (1815-1894) was born into a family of a well-educated village priest. Deep faith and spirituality were instilled into him at an early age. After graduating from church college and seminary, he was admitted, as one of the best students, to the Kiev Theological Academy. Subsequently, he spent six years serving in the Russian Ecclesiastical Mission in Jerusalem, then a year in Constantinople. He also traveled throughout Europe. He worked his way from a Latin teacher to the rector of the most prestigious theological academy in Russia. Knowledge of ancient languages, as well as of French and German to varying degrees, allowed him to read in the original the works of ancient and modern authors.

In 1859 , he was promoted to the rank of bishop. However, after a short-term administration of the vast Diocese of Vladimir (1863-1866) with its 1255000 inhabitants, 28 monasteries and 1152 parishes, he petitioned for retirement. In 1866 , he retired to the Vyshensky Monastery, where he stayed until his death in 1894. From 1872 to 1894 , he lived in seclusion. During that period, he extensively corresponded with monks and laics. He also translated into Russian works of Greek fathers. His Russian edition of the "Philokalia", his interpretation of St Paul's Epistles, his letters about spiritual life and his writings on the salvation of the soul saw the light of day when Theophan lived in seclusion.

Bishop Theophan was a prolific writer, but he did not seek to create a dogmatic or philosophical system. First and foremost, he was a teacher of morality and practical spirituality. Based on patristic ascetic literature, he developed a coherent concept of upbringing, aimed at releasing and putting in practice the individual potential of a person ${ }^{3}$. And we owe the saint for that.

The researchers of St. Theophan's anthropology agree on the conclusion that he distinguished three parts in human nature: the body, the soul and the spirit

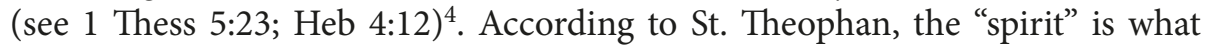
the Holy Fathers called the "mind"5. He wrote the following: "I suppose that according to Saint Anthony, our soul is akin to the soul of animals. What makes

${ }^{1}$ Berlin I. Russian Thinkers. London: Penguin, 1978. P. 136.

${ }^{2}$ Kulakov $M$. The infinite diversity of persons: individual personality in the ascetical theology of St. Theofan the Recluse (1815-1894). Dr. Sci. Thesis in Philology. University of Oxford, 2000. P. 63.

${ }^{3}$ Никулина Е.Н. Антрополого-педагогические воззрения святителя Феофана Затворника: дис. ... канд. пед. наук. М.: Институт стратегии развития образования Российской академии образования, 2016. С. 4.

${ }^{4}$ Питирим (Творогов), иеромонах. Некоторые аспекты антропологии святителя Феофана Затворника // Феофановские чтения. Вып. 5. Рязань: Рязанский государственный университет им. С. А.Есенина, 2012. С. 145.

${ }^{5}$ Святитель Феофан Затворник. Толкование Послания апостола Павла к Римлянам (главы 1-8). М.: Правило веры, 2006. С. 579-580. 
us different from them is the mind (voũ), which I call the spirit. What he [Saint Anthony] says about the mind I denote as the spirit" 6 . The spirit is the highest faculty of human nature, the breath of life that God breathed into his nostrils ${ }^{7}$. The characteristics of the human spirit are the fear of God, conscience (the natural tables of the Law of God) and the thirst of God. It is the spirit that makes us different from the animals. Human dignity manifests itself in man's ability to act spiritually. Objecting to materialists, Theophan speaks about a special, "exalted" status of man in the world of beings created by God. If man lives "according to the flesh", he becomes akin to an animal. If he lives "in spirit", he becomes akin to an angel.

St. Theophan divided all actions of the soul into three categories - thoughts, desires and feelings ${ }^{8}$. Memory and imagination represent the basis for human mental activity. What memory has not preserved cannot be dreamed about. Imagination and memory do not think on their own. These are the faculties of the soul controlled by reason. Through reason, a person, analyzing and weighing up opinions and assumptions, takes decisions. Decisions are thoughts that have acquired a certain shape. The set of mind-shaped thoughts that accumulate in the memory constitutes the mindset of a person. The more thoughts and clear perceptions about things a person has, the wider his or her scope of knowledge is. Coherent knowledge constitutes the science of objects under study. "Science is

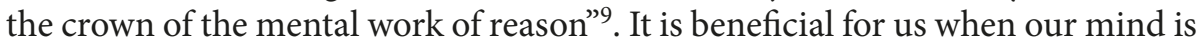
occupied with reflection on the reality in order to shape certain concepts about it. Under the influence of the spirit, the human soul strives for ideality. The set of well-established concepts forms one's world view. When the set of views is ideal, St. Theophan defines it as metaphysics or "true philosophy" 10 . Inspired by the spirit, the soul of such a philosopher rushes into the invisible and infinite sphere of contemplation of all things in God. When a person digs out of his or her memory the "useless trash" of recollections and, following "the laws of conjunction of ideas", starts wandering in his or her thoughts, adding fantasies to recollections, he (or she) enters into a state of dreamful sleeping or, in other words, indulges in "idle thinking"11.

Man's desires are governed by his will. The will restrains or releases all the forces of the soul and the body. The will, in turn, is governed by the zeal, which seeks to acquire something pleasant, useful and necessary. Everyday needs (be it

${ }^{6}$ Святитель Феобан Затворник. Начертание христианского нравоучения. М.: Московское подворье Псково-Печерского Свято-Успенского монастыря, 1994. С.189, сноска. - In this quotation, as Mikhail Kulakov believes, Theophan refers to the controversial fragment of "Philokalia", which does not belong to Saint Anthony (Kulakov M. The infinite diversity of persons... P. 157).

${ }^{7}$ Святитель Феофан Затворник. Письма о разных предметах веры и жизни. М.: Правило веры, 2007. С. 231.

${ }^{8}$ Святитель Феофан Затворник. Что есть духовная жизнь и как на нее настроиться. М.: Правило веры, 2009. С. 21.

${ }^{9}$ Ibid. C. 24.

${ }^{10}$ Ibid. C. 44.

${ }^{11}$ Ibid. C. 25. 
family or community needs) incite the desire to find satisfaction in them. "Desire always aims at a certain object that can satisfy the need"12. Choosing between the desired items, man takes a decision and finds the means to fulfil his wishes. Regularity in making specific choices develops the skill of taking decisions instantly, without thinking. The set of skills and personal rules establish the lifestyle of a person. "By knowing a person's way of life, one can guess what he (or she) thinks at a certain point of time and how he (or she) is likely to act under certain circumstances"13. Prudence is the ability to correlate goals with means so that actions result in success. A reasonable person determines the way, the method and the measure of satisfying his or her desires stemming from his or her needs to make his or her life pleasant. Inspired by the spirit, the person feels the urge to pursue good deeds even at the expense of his or her own well-being ${ }^{14}$.

The heart is the center of human life, it feels everything that is of concern to us. All we see, hear, taste, smell or touch, our healthy condition or illness, our memories and reflections, all we did or plan to do, all of this brings pleasure or unpleasure to our heart. Everything that impacts on us generates in us specific feelings that are sometimes beyond description. If the heart takes a liking to a certain object, it gives energy to the will and the mind. On the contrary, if it does not like an object, we lose interest in it and do not finish what we have planned to accomplish. When wisdom reigns in thoughts and prudence in deeds, the heart experiences happiness. When thoughts wander and feelings get carried away by passionate desires and not by natural needs, the heart loses peace and suffers ${ }^{15}$. The heart can be given free rein only if is purified from passions. Under the influence of the spirit, man starts feeling inclination towards beauty and grace. "Graceful works of art delight us not only by the beauty of their form, but rather by the beauty of their content, by the ideal beauty that can be contemplated intelligently" 16 .

If the forces of our soul are upset, we feel dissatisfied with our life. On the contrary, when they act in accordance with their "inherent laws" established by God, man lives in harmony with himself and experiences joy and happiness. The spirit aspires to contemplating the beauty of God and enjoying it. This is "its life and the celestial life itself" 17 .

According to Theophan the Recluse, reflections about the composition of human nature are supposed to help man "know himself" and tune himself to spiritual life. "If we develop the right concepts about the constitution of the human being, we will get the surest indication as to how the human being should live"18.
12 Ibid. C. 27.
13 Ibid. C. 29.
${ }^{14}$ Ibid. C. 45
15 Ibid. C. 33.
${ }^{16}$ Ibid. C. 46
17 Ibid. C. 47.
${ }^{18}$ Ibid. C. 17. 
Being above all preoccupied by human salvation, he resorts to a trichotomic scheme in order to show explicitly how man with his two natures (body and soul) can exist on three ontological levels: physical, mental and spiritual. The soul and the spirit are not two separate substances, they are the abilities of the human spirit to unite with the Holy Spirit through the Word of God and to transform a natural body into a spiritual one ${ }^{19}$. The human spirit is the highest faculty of the soul, which is characterized by the fear of God, conscience and striving for communion with God.

In St. Theophan's "Essay on Christian morality" we find the most complete picture of his anthropological concepts. Man is an independent being who acts freely and observes the results of his actions. Man is a living creature that tends to evolve. The "growth of the human spiritual body" occurs through the accumulation and "digestion" of thoughts, feelings, desires and deeds ${ }^{20}$. The immortality of the soul implies its infinite improvement ${ }^{21}$.

Bishop Theophan does not use the terms "hypostasis" and "individuality"22. He prefers concepts such as "personality", "man" and "self" 23 . According to him, "person" is the point of conjunction of all human powers and abilities. A "person" possessing self-consciousness, freedom and life is destined to rise above them and to become their master ${ }^{24}$. "The personality of man (of his self) is the unity of the spirit, the soul and the body" 25 . The "person" is a personality, it is our "self", "the alliance and indivisible unity of all forces"26. At the same time, according to the Bishop, personality "cannot be equated with nature and reduced to its manifestations. Personality is above nature. It should be capable of rising above all natural forces and movements and of controlling them"27.

Consciousness is an essential human quality. It allows man to define himself as "I" and to distinguish himself as a separate person. Through consciousness man distinguishes his existence from the existence of things that are external to him. "When he speaks about himself, he says 'I' and not 'they', and when he speaks about 'them', he says 'they' and not 'I"' 28 .

19 Ibid.

${ }^{20}$ Ibid.

21 Феофан Затворник, святитель. Начертание христианского нравоучения. С. 94.

${ }^{22}$ Хондзинский П.В. Антропология святителя Феофана Затворника и зарождение первых персоналистических концепций в русском богословии // Вестник Православного Свято-Тихоновского гуманитарного университета. Сер. 1. Богословие. Философия. 2017. № 70. C. 14.

${ }^{23}$ Никулина Е. Н. Понятие личности в антропологии святителя Феофана Затворника // Вестник Православного Свято-Тихоновского гуманитарного университета. Сер. 4. Педагогика. Психология. 2007. № 2. С. 166.

${ }^{24}$ Никулина Е.Н. Антрополого-педагогические воззрения святителя Феофана Затворника. С. 11.

${ }^{25}$ Святитель Феофан Затворник. Начертание христианского нравоучения. С. 127.

${ }^{26}$ Ibid.

${ }^{27}$ Никулина Е.Н. Понятие личности в антропологии святителя Феофана Затворника. С. 166.

${ }^{28}$ Святитель Феофан Затворник. Начертание христианского нравоучения. С. 127. 
When man's attention is directed inwardly, St. Theophan calls it "self-consciousness". Interpreting St Paul's Epistle to the Romans, he links "self-consciousness" with the biblical concept of the heart, which is perceived as the center of man's intellectual life: "The heart is an inner person or the spirit, embracing selfconsciousness, conscience, the notion of God and the feeling of dependence on Him"29. "Self- consciousness" is not just the ability to distinguish oneself from other people, it is the awareness of our responsibility for our actions, for which we will be held accountable ${ }^{30}$. Children and people with mental illnesses ("those who are out of their mind") are not predisposed to high moral behavior. Children, because of their age, have not yet come to self-consciousness ${ }^{31}$. Those who are mentally handicapped and deprived of reason are "immersed in sleep" 32 . Selfconsciousness of those who are governed by passions and are devoid of grace is also far from being perfect. "The sinner does not know himself well"33, he does not distinguish himself and his actions, and therefore, he is blind, dwells in darkness and self-oblivion (see Eph 5:14; 2 Pet 1:9).

The awakening of the sinner, his becoming light in the Lord (Eph. 5:8), is possible only through God's grace, which is given in the sacraments of baptism and penance. Through baptism, the human mind changes as if it were reborn. In baptism, man consciously renounces Satan and all his evil deeds and promises to serve Jesus Christ the Son of God ${ }^{34}$. In response to his determination, God's grace blends with his spirit ${ }^{35}$. Through the grace of God, the moral force, born as the first inspiration, is imprinted in his spirit and remains with him forever. Thus, baptism becomes the "beginning of salvation" and the "new life" 36 . The state of man purified by God's grace through reading the Holy Scripture and ascetic literature is defined by St. Theophan as "watchfulness and sobriety" (see 1 Pet $5: 8,4: 7)^{37}$.

Following in the footsteps of the Fathers of the "Philokalia", St. Theophan understands self-knowledge as a process of restoring the original human dignity and glory, which is impossible without the synergy of the divine and the human in the prayer. However, reflecting on the subject of self-knowledge, Theophan introduces his own understanding of psychology of Personality. In his opinion, self-knowledge is acquired through the gradual development of spiritual selfawareness. This approach, which is found neither in the works of St. Ignatius Brianchaninov nor in the writings of Optina Startsy, is a distinctive feature of the concepts developed by Theophan the Recluse.

${ }^{29}$ Святитель Феобан Затворник. Толкование Послания апостола Павла к Римлянам (главы 1-8). С. 133.

${ }^{30}$ Святитель Феобан Затворник. Начертание христианского нравоучения. С. 48.

${ }^{31}$ Ibid. C. 298.

32 Ibid. C. 127.

33 Ibid. C. 137.

${ }^{34}$ Ibid. C. 49.

${ }^{35}$ Ibid. C. 43.

${ }^{36}$ Святитель Феофан Затворник. Письма о разных предметах веры и жизни. С. 230.

${ }^{37}$ Святитель Феобан Затворник. Начертание христианского нравоучения. С. 138. 
Whether we will live morally or immorally is our own choice. Like any other biological creature, man is able to distinguish himself from the external world and, therefore, he is also able to preserve his personality. Man is a conscious being by his nature. However, his life can be called morally conscious only when his will matches the will of God. Our life and its direction depend on what we love. When we love something, our consciousness and will cling to the object of our love ${ }^{38}$. When our mind and will are with the spirit, we become spiritual; when they are with the soul - we are men of emotions, and when they are with the flesh - we are the people of the flesh.

Consequently, if we follow Saint Theophan, as noted by Archpriest Pavel Khondzinsky, in man "it is necessary to make a distinction between freedom as his choice and freedom as his spiritual (rational) knowledge of the truth" ${ }^{39}$. The spirit participates in the decision-making process by revealing the will of God to man through his conscience, his soul with its own needs and his consciousness, weighing on the scales of the mind all pros et cons. Theophan the Recluse distinguishes between the empirical "self", arising from contact with the phenomenal world, and moral self-consciousness. According to Khondzinsky, in order to describe the correlation between the "self" and consciousness, St. Theophan uses both the old metaphysical terminology based on the teachings of the Holy Fathers and the new psychological terminology that he studied at the Kiev Theological Academy ${ }^{40}$.

The anthropology of Bishop Theophan stems from the Holy Scripture, Eastern Christian ascetic literature, his own observations, as well as some ideas put forward by the representatives of the Kiev school of philosophy, in particular P. S. Avsenev, archimandrite Innokentiy (Borisov), O. M. Novitsky, I. M. Skvortsov. Apparently, under the influence of lectures on "moral philosophy" delivered by professors of the Kiev Academy, Theophan the Recluse introduced the concept of "Christian psychology", by which he actually meant "anthropology" 41 . The equation between anthropology and psychology was established by his teacher at the Kiev Academy, Peter Avsenev ${ }^{42}$.

Professor P.A.Avsenev's lectures on consciousness, mental illness, sleep, hypnosis, sleepwalking and death were a great success and encouraged students to in-depth reflection ${ }^{43}$. His "Psychology Notes" were written under the influence of Schubert's "History of the Soul" 44 , a reference textbook on psychology in Russian seminaries and academies in the first half of the $19^{\text {th }}$ century ${ }^{45}$.

38 Святитель Феофан Затворник. Толкование Послания апостола Павла к Римлянам (главы 1-8). С. 490.

39 Хондзинский П. В. Антропология святителя Феофана Затворника... С. 17.

40 Ibid. C. 25.

41 Святитель Феофан Затворник. Начертание христианского нравоучения. С. 8.

42 Феобан (Авсенев), архимандрит. Из записок по психологии. Киев, 1869. С.2.

43 Ряполов С. В. Философская концепция архимандрита Феофана (Авсенева) // Христианское чтение. 2015. № 3. С. 33 .

${ }^{44}$ Schubert G. H. Geschichte der Seele. 2 vols. Stuttgart: Gottafchen Buchhandlung, 1830.

${ }^{45}$ Kulakov M. The infinite diversity of persons... P. 155. 
Archpriest Georgy Florovsky notes that in one of his letters about the universal animation of the world, Theophan directly refers to Schubert (1780-1860) and Avsenev (1810-1851) ${ }^{46}$.

Avsenev believed that the spirit was the highest faculty of the soul, its conscience and self-consciousness and the imprint of the image of God ${ }^{47}$. Man receives the latter the moment he is born. However, in order to attain to the likeness of God, he needs to undergo the growth from child to man (1 Cor 13:11) and become rooted in $\mathrm{God}^{48}$. It is in the nature of the spirit to seek God ${ }^{49}$. The spirit gives to the inclinations of the soul, which human beings share with animals, "a higher aspiration and a spiritual goal", contributes to their transformation and refinement ${ }^{50}$.

The soul has an innate desire to know, enjoy and act. Aspiring to the Creator, the spirit acquires "the light of truth" by means of knowledge. Looking for enjoyment in God, the soul develops a "sense of beauty". The activity of the spirit oriented towards divine holiness strengthens the human will in the struggle against evil and elevates the soul from one degree of perfection to another ${ }^{51}$. The soul animates the body. But the body is not a vehicle of the soul. The soul does not come into being before the body, it is born simultaneously with it. Born of the parents, the soul and the body inherit their nature. At the same time, since the power of God acts in the birth of (all) living beings, the soul is God's creation, "no matter how it comes into existence"52. Following P. S. Avsenev, St. Theophan examines the human body in its connection with the soul and the spirit, analyzes the genesis of the passions at body level and provides recommendations concerning the ascetic means to combat the passions.

In his writings, Theophan rarely gives references to the sources from which he draws ideas for subsequent reflection on them. Although he consistently criticizes German theology as non-Orthodox ${ }^{53}$, his positive statements about certain Germans, including Schubert ${ }^{54}$, suggest that his generally critical attitude towards them does not prevent him from using their terminology.

The same can be said about the Encyclopedia of Philosophical Sciences composed by G. Hegel from which St. Theophan borrowed certain ideas. In particular, this concerns his ideas about the process of the cognitive activity

46 Флоровский Георгий, прот. Пути русского богословия. Минск: Изд-во Белорусского экзархата, 2006. С. 391.

47 Феофан (Авсенев), архимандрит. Из записок по психологии. С. 24.

48 Святитель Феобан Затворник. Начертание христианского нравоучения. С. 91.

${ }^{49}$ Ibid. C. 36.

${ }^{50}$ Ibid. C. 50.

51 Феобан (Авсенев), архимандрит. Из записок по психологии. С. 54.

52 Ibid. C. 215.

${ }^{53}$ Святитель Феофан Затворник. Собрание писем. М., 1901. Вып. VII. С. 209-210.

54 "I remember lecture on that delivered to us by Avsenev, first as Peter Semenovich, and then as archim. Theophane. ...Here is the unity of nature. I remember that in Schubert's Geschichte der Seele, History of the soul, these provisions are revealed in detail. This properly agrees with the fall and the atonement" (Феофан (Говоров), епископ. Собрание писем. Вып. 2. М.: Изд. Афонского Русского Пантелеимонова монастыря, 1898. С. 109). 
of the human spirit from the Hegelian Philosophy of Spirit $(1830)^{55}$. Like in St. Theophan's works, "spirit" (Geist) is the key concept in Hegel's philosophy. "Spirit" is the unifying principle of consciousness and will ${ }^{56}$. It "knows itself as embodying - itself in itself and filling itself out of itself... spirit enters into reality as will, and as knowledge, it lies in the universality of the concept" 57 . Like Theophan the Recluse, Hegel maintains that "spirit" is the "likeness of God", "the divine (principle) in man" ${ }^{58}$. However, contrary to Theophan, Hegel does not see in spirit "the breath of God", he regards it as mind, which is absolutely identical to itself, "absolute self-determination" 59 . According to Hegel, God does not have a separate hypostasis and substance, God is moral self-consciousness, thinking morality. Morality is the "divine spirit" inherent in self-consciousness ${ }^{60}$. There is no religion beyond the moral spirit ${ }^{61}$. Theophan the Recluse qualifies the "fashionable ideas" of the German philosopher as "nonsense"62. In his opinion, Hegel, as well as Fichte, belong to the "godless", because their ideas about the "world soul" lead to the dissolution of God in the world ${ }^{63}$.

Nevertheless, according to Elena Nikulina, "Hegel's discourse on the stages of human development was apparently one of the sources of the developmental pedagogy of St. Theophan" 64 . This can be traced in similar descriptions of childhood and adolescence, as well as in characteristics relating to the gradual transition of adolescence into adulthood.

Nikulina cites numerous examples of Hegelian ideas borrowed by Bishop Theophan. Hegel, for example, points at "the desire of children to imitate" 65 . St. Theophan also says that "children like to imitate" 66 . According to Theophan the Recluse, teaching children how to develop will is reduced to "complete obedience and submission to the will of the parents" 67 . Hegel underlines the importance of subordination to the "rational will coming from outside", which children

${ }^{55}$ Hegel G. W. F. Enzyklopädie der philosophischen Wissenschaften im Grundrisse. Frankfurt am Main: Suhrkamp, 1981.

56 Торубарова Т.В. Понятие духа в философии Гегеля // Научные ведомости Белгородского государственного университета. Сер. Философия. Социология. Право. 2016. № 3 (224). C. 19.

${ }^{57}$ Гегель Г. В. Ф. Энциклопедия философских наук. Т. 1. Наука логики. М., 1974. С. 311.

58 Гегель Г.В.Ф. Энциклопедия философских наук. Т.3. Философия духа. М., 1977. C. 257.

${ }^{59}$ Ibid. C. 254.

${ }^{60}$ Ibid. C. 373.

${ }^{61}$ Ibid. C. 372.

${ }^{62}$ Святитель Феофан Затворник. Письма о христианской жизни. М.: Правило веры, 2007. С. 135.

${ }^{63}$ Святитель Феофан Затворник. Начертание христианского нравоучения. С. 240.

${ }^{64}$ Никулина Е.Н. Идеи Г. Гегеля в педагогическом наследии святителя Феофана Затворника // Вестник Православного Свято-Тихоновского гуманитарного университета. Сер. 4. Педагогика. Психология. 2016. № 4 (43). С. 83.

${ }^{65}$ Гегель Г.В. Ф. Философия духа. С. 85.

${ }^{66}$ Святитель Феофан Затворник. Путь ко спасению. Краткий очерк аскетики. М.: Правило веры, 2008. С.73.

${ }^{67}$ Ibid. 
"gradually appropriate", as "the child... at the early stage of its development... has no awareness of good or evil" 68 . Hegel incites to fight against "self-will" as the "germ of evil" and permissiveness: "if we let the children do whatever they want... they will develop a regrettable habit of being totally unrestrained"69. A similar idea is present in the works of St. Theophan: "A child left to itself is made unrestrainedly self-willed"70. In order to protect the unbridled nature of the child from mistakes, Theophan recommends instilling into children a sense of "moral duty". Hegel also speaks of the need for higher authority and discipline: "obedience is the beginning of all wisdom"71.

According to Bishop Theophan, the main purpose of education is the conscious acceptance of Christian faith, which is associated with the vow "to be a true Christian"72. All education should be directed towards this goal. At the same time, "it is impossible to establish when one comes to the stage of perceiving oneself as Christian and becomes consciously determined to live a Christian life. In fact, it happens at different ages: at the age of 7, 10, 15 or later"73. In the context of developmental psychology, the convictions of a young man should be gradually "appropriated" by himself, become "his own"74. In addition, Hegel notes a particular turning point in the life of a young man, when after having gradually accumulated knowledge about religion and morality, he begins to lead a conscious Christian life: "As soon as he appropriates all this, he achieves independence, and that is the beginning of will, deriving out of itself. Theoretically still an adolescent, he now finds support in himself" 75 .

As Elena Nikulina concludes, “despite St Theophan's negative attitude towards Hegel's philosophy in general, the existence of parallels between his works and Hegelian anthropology demonstrates Bishop's approach to selecting material from sources, out of which he borrowed and further developed ideas of even those authors with whom he had serious ideological (and religious) disagreements"76.

The main objective of St. Theophane's instructions is to ensure the development of integral personality. His methods are based on the principle of gradual development of natural forces (spiritual, mental, physical) in man and primarily in children.

When examining the ideas of Theophan the Recluse on pedagogy, it is often noted that in his writings he used the terms "mind", "will" and "heart", typical of the psychology and pedagogy of his time (Archbishop Eusebius (Orlinsky),

\footnotetext{
${ }^{68}$ Гегель Г.В. Ф. Философия духа. С. 86.

${ }^{69}$ Ibid.

${ }^{70}$ Святитель Феофан Затворник. Путь ко спасению. С. 72.

${ }^{71}$ Гегель Г.В.Ф. Философия духа. С. 86.

${ }^{72}$ Святитель Феофан Затворник. Путь ко спасению. С. 89.

${ }^{73}$ Ibid. C. 79.

${ }^{74}$ Ibid. C. 41.

75 Гегель Г. В. Ф. Лекции по философии духа. М.: Дело, 2014. С. 65-66.

${ }^{76}$ Никулина Е.Н. Идеи Г. Гегеля в педагогическом наследии святителя Феофана За-
} творника. С. 85 . 
V. N. Karpov, I.A. Kedrov, P. M.Lyubovsky, O. M. Novitsky, P.Z. Timoshenko, P. D. Yurkevich). He correlated this terminology with the patristic doctrine on three faculties of the soul, which in his personal reading were presented as "rationality", "will" and "emotional feelings". As a graduate of the Kiev Theological School, St. Theophan the Recluse was familiar with modern era philosophy. However, using new forms of describing human nature, he maintained "the balance between the ancient patristic tradition and the anthropological discoveries of modernity"77.

Despite the existence of parallels in particulars, which may indicate that St. Theophan was well familiar with contemporary literature on psychology, he elaborated a fundamentally different pedagogical approach. The developmental pedagogy of the Saint is built around the task of preserving the grace of baptism, which helps ensure the integrity of man with his faculties and facilitates his "way to salvation".

\section{References}

Berlin I. (1978) Russian Thinkers. London, Penguin.

Florovsky George, prot. (2006) Ways of Russian theology. Minsk, Publishing house of the Belarusian Exarchate. (In Russian)

Hegel G. W. F. (1974) Encyclopedia of Philosophical Sciences. Vol. 1. The science of logic. Rus. ed. Moscow, Mysl' Publ. (In Russian)

Hegel G.W.F. (1977) Encyclopedia of Philosophical Sciences. Vol.3. The philosophy of the spirit. Rus. ed. Moscow, Mysl' Publ. (In Russian)

Hegel G. W. F. (1981) Enzyklopädie der philosophischen Wissenschaften im Grundrisse. Frankfurt am Main, Suhrkamp.

Hegel G.W.F. (2014) Lectures on the philosophy of the spirit. Rus. ed. Moscow, Delo Publ. (In Russian)

Khondzinsky P.V. (2017) "Anthropology of St. Theophan the Recluse and the birth of the first personalistic concepts in Russian theology", in Vestnik Pravoslavnogo Sviato-Tikhonovskogo gumanitarnogo universiteta. Seriia 1. Bogoslovie. Filosofiia, no. 70, pp. 11-27. (In Russian)

Kulakov M. (2000) The infinite diversity of persons: individual personality in the ascetical theology of St. Theofan the Recluse (1815-1894). Dr. Sci. Thesis in Philology. Oxford, University of Oxford.

Nikulina E.N. (2007) "The concept of personality in the anthropology of St. Theophan the Recluse", in Vestnik Pravoslavnogo Sviato-Tikhonovskogo gumanitarnogo universiteta. Seriia 4. Pedagogika. Psikhologiia, no. 2, pp. 165-176.

Nikulina E. N. (2016) "Ideas of Hegel in the pedagogical heritage of St. Theophan the Recluse", in Vestnik Pravoslavnogo Sviato-Tikhonovskogo gumanitarnogo universiteta. Seriia 4. Pedagogika. Psikhologiia, no. 4 (43), pp. 81-87.

Nikulina E.N. (2016) Anthropological and pedagogical views of St. Theophan the Recluse. PhD thesis in Pedagogy. Moscow, Institut strategii razvitiia obrazovaniia Rossiiskoi akademii obrazovaniia.

Pitirim (Tvorogov), hieromonk. (2012) "Some aspects of the anthropology of St. Theophan the Recluse", in Feofanovskie chteniia, vol. 5. Ryazan, Riazanskii gosudarstvennyi universitet im. S. A. Esenina Publ., pp. 144-151.

Ryapolov S.V. (2015) “The philosophical concept of Archimandrite Theophane (Avsenev)", in Khristianskoe chtenie, no. 3, pp. 31-43.

77 Хондзинский П. В. Антропология святителя Феофана Затворника... С. 25. 
Schubert G. H. (1830) Geschichte der Seele. In 2 vols. Stuttgart, Gottafchen Buchhandlung.

St. Theophan the Recluse (1901). A collection of letters. Vol. VII. Moscow, Izdanie Afonskogo Russkogo Panteleimonova monastyria Publ. (In Russian)

St. Theophan the Recluse (1994). Inscription of Christian moralizing. Moscow, Moskovskoe podvor'e Pskovo-Pecherskogo Sviato-Uspenskogo monastyria Publ. (In Russian)

St. Theophan the Recluse (2006). Interpretation of the Epistle of Paul the Apostle to the Romans (chapters 1-8). Moscow, Pravilo very Publ. (In Russian)

St. Theophan the Recluse (2007). Letters about Christian life. Moscow, Pravilo very Publ. (In Russian)

St. Theophan the Recluse (2007). Letters about different subjects of faith and life. Moscow, Pravilo very Publ. (In Russian)

St. Theophan the Recluse (2008). The path to salvation. A brief sketch on asceticism. Moscow, Pravilo very Publ. (In Russian)

St. Theophan the Recluse (2009). What is spiritual life and how to set up for it. Moscow, Pravilo very Publ. (In Russian)

Theophan (Avsenev), archimandrite (1869). From notes on psychology. Kiev, Tipografiia Kievskogo Gubernskogo Upravleniia Publ. (In Russian)

Theophan (Govorov), bishop (1898). A collection of letters. Vol. II. Moscow, Izdanie Afonskogo Russkogo Panteleimonova monastyria Publ. (In Russian)

Torubarova T. V. (2016) “The concept of spirit in the philosophy of Hegel”, in Nauchnye vedomosti Belgorodskogo gosudarstvennogo universiteta. Seriia Filosofiia. Sotsiologiia, no. 3 (224), pp. 19-35.

Received: October 1, 2020

Accepted: November 19, 2020

Author's information:

Hieromonk Iriney (Ivan V.Pikovskiy) — Lecturer; irenaeus@mail.ru

\section{Взаимосвязь антропологии и психологии в трудах святителя Феофана Затворника}

\section{Иеромонах Ириней (Пиковский)}

Сретенская духовная семинария,

Российская Федерация, 107031, Москва, ул. Большая Лубянка, 19

Для цитирования: Pikovskiy I. V. Interrelation between anthropology and psychology in the works of St. Theophan the Recluse // Вопросы теологии. 2021. Т.3, № 1. С.45-57. https://doi.org/10.21638/spbu28.2021.103

Сочинения святителя Феофана Затворника о христианской этике считаются базовыми в изучении истории формирования христианской психологии в России. Стиль повествования (в частности, характер лексики) творений епископа Феофана (Говорова) содержит отголоски его русской редакции «Добротолюбия». Однако вопреки расхожему представлению о том, что Феофан мыслил исключительно языком Святых Отцов, в статье приводятся примеры заимствования святителем некоторых идей из классической немецкой философии романтизма. Под влиянием учителей из Киевской духовной академии (например, П.А. Авсенева) он обращается к теме «духа человеческого». Споря с представителями натурфилософии, которых он не называет по имени, Феофан утверждает, что дух - это высшая часть природы человека, дыхание 
жизни, тот образ Божий, благодаря которому человек имеет возможность общения с Творцом. Для святителя Феофана, как и для многих других академических ученых середины XIX в., понятия «нравственная философия», «антропология» и «психология» были взаимозаменяемыми. Показано, что в вопросах психологии и педагогики размышления Феофана Затворника строятся по той же модели, которая активно разрабатывалась философами Нового времени (Шеллинг, Гегель). Несмотря на серьезные мировоззренческие разногласия в отношении религии, святитель Феофан воспринимает, фильтрует и продолжает развивать некоторые идеи, восходящие к немецкой философии.

Ключевые слова: антропология, психология, лицо, личность, русское богословие, святитель Феофан Затворник, воспитание, обет крещения.

Статья поступила в редакцию 1 октября 2020 г. Статья рекомендована к печати 19 ноября 2020 г.

Информация об авторе:

Иеромонах Ириней (Пиковский Иван Витальевич) — преп.; irenaeus@mail.ru 